\title{
SEMIOTIKA PADA POSTER IKLAN AIDS PERANCIS VERSI 'SCORPION' TBWA PARIS
}

\author{
Deni Albar \\ Program Studi Desain Komunikasi Visual, Universitas Komputer Indonesia
}

\begin{abstract}
Abstrak. Poster iklan layanan masyarakat tentang AIDS ini dibuat oleh agensi TBWA Paris, Perancis sebagai poster nasional dalam kampanye sosial pencegahan HIV Aids dengan penggunaan kondom. Pengalamat atau pengirim dalam hal ini AIDES Perancis pada khususnya, mencoba memberikan suatu pesan pada masyarakatnya atau penerima dari poster. Reaksi berdatangan dari audiens, baik respon positif maupun respon negatif. Respon-respon diatas merupakan gambaran akan bagaimana suatu tanda diterima di masyarakat, baik yang memahami maupun yang memang benar-benar tidak memahami maksud dari iklan tersebut. Tentunya hal tersebut berkaitan dengan budaya, tingkat pendidikan dan lain sebagainya. Menarik apabila hal ini dikaji dengan semiotika, sehingga tentunya dapat di interpretasikan dengan lebih baik. Penelitian ini menggunakan pendekatan semiotika. Dalam poster iklan AIDS versi Scorpion ini, dapat ditelaah berdasarkan denotasi dan konotasi yang muncul dalam setiap objek yang ada. Hasil dapat disimpulkan dengan Poster iklan kampanye layanan masyarakat mengenai penggunaan kondom untuk hubungan seks yang aman ini menggunakan metafora. Konsep utama yang ingin disampaikan adalah untuk berhati-hati dalam melakukan hubungan seks, dimana pasangan yang bisa ditemukan sembarangan bisa saja menyandang virus HIV Aids yang bisa menyengat secara perlahan-lahan tanpa disadari. Pesan ini dimetaforakan dengan imaji kalajengking hitam besar. Pesan imaji diperkuat dengan pesan linguistik untuk menggunakan kondom agar terjaga dari virus HIV AIDS.
\end{abstract}

Kata kunci: Semiotika, Poster, AIDS

\section{PENDAHULUAN}

Poster iklan AIDS versi Scorpion dibuat oleh agensi TBWA Paris, Perancis dalam kampanye AIDES - Without a condom, you're sleeping with aids dikota BoulogneBillancourt. Poster AIDS versi Scorpion ini dikeluarkan tahun 2004 dengan creative director Erik Vervroegen, art director Cedric Moutaud, copywriter Guillaume Chifflot dan photographer Dimitri Daniloff. Beberapa kalangan menjadikan poster 
ini sebagai guyonan, dalam beberapa forum di internet seperti di www.theinspirationroom.com (2007), respon-respon negatif seperti „Yup, jangan pernah bercinta dengan kalajengking, sebab bisa menularkan HIV", dan "Mana ada kalajengking sebesar itu!","Ohida disamakan dengan kalajengking, pelecehan !" dan masih banyak lagi respon lainnya termasuk respon-respon positif seperti "Waw, iklan yang bagus, langsung menyadarkan akan bahaya HIV". Responrespon diatas merupakan gambaran akan bagaimana suatu tanda diterima di masyarakat, baik yang memahami maupun yang memang benar-benar tidak memahami maksud dari iklan tersebut. Tentunya hal tersebut berkaitan dengan budaya, tingkat pendidikan dan lain sebagainya. Namun, apabila dikaji dengan semiotika, barangkali dapat di interpretasikan dengan lebih baik. Banyak kritikan ditujukan pada poster kampanye AIDS ini dimana seseorang pengidap HIV disamakan dengan monster.

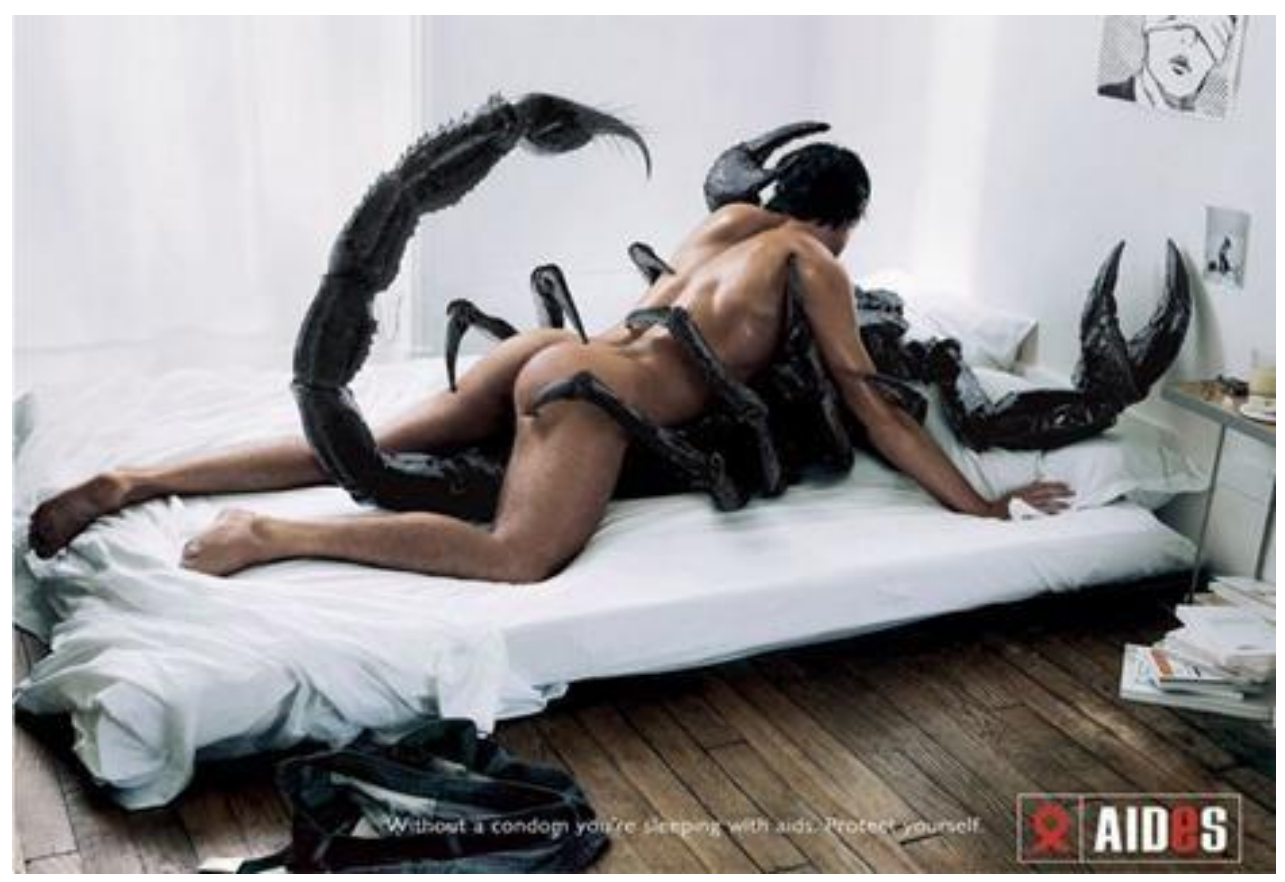

Sumber: http://theinspirationroom.com/daily/print/2007/12/aids_Scorpion.jpg (01 Agustus 2009) 


\section{METODE \& PEMBAHASAN}

Dalam poster iklan AIDS ini, dapat ditelaah berdasarkan denotasi dan konotasi yang muncul dalam setiap objek yang ada. Teori semiotika Ferdinand de Saussure yang dikembangkan oleh Roland Barthes dimana bahwa tanda denotatif terdiri atas penanda dan petanda. Akan tetapi, pada saat bersamaan, tanda denotatif adalah juga penanda konotatif. Di dalam semiologi Barthes, denotasi merupakan sistem signifikasi tingkat pertama, sementara konotasi merupakan tingkat kedua. Visualisasi dalam poster menampilkan imaji seorang lelaki yang melakukan adegan seks dengan kalajengking besar dimana lelaki berada diatas kalajengking, latarnya adalah sebuah kamar dengan lantai kayu, kasur busa tanpa ranjang, poster lelaki tertutup mata, kemudian segelas minuman dan celana jeans serta buku-buku tertumpuk tidak rapih di bawah meja kecil. Dari imaji yang muncul tersebut, maka bisa diuraikan sebagai berikut;

\section{Tanda (Denotasi \& Konotasi)}

Berikut merupakan tanda-tanda yang terdapat dalam poster AIDS dari TBWA Paris versi Scorpion tahun 2004;

\section{a. Pesan Linguistik}

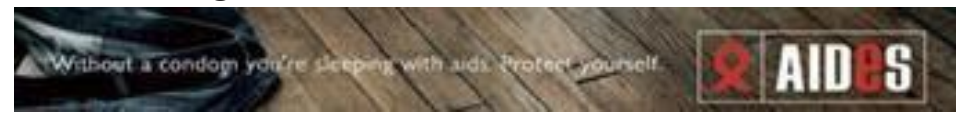

Teks "AIDeS" sebagai denotasi pada pojok kanan bawah merupakan juga sebuah konotasi dari sebuah virus berbahaya sekaligus menyatakan makna sebagai penegas iklan layanan masyarakat AIDS. Dimana huruf "e" diwarnai merah sehingga teks kata lebih mendorong untuk terbaca AIDS. Tulisan kalimat, "Without a condom you're sleeping with aids. Protect yourself." Memiliki makna harfiah serta makna petunjuk dan anjuran dalam melakukan hubungan seks dengan cara aman. 


\section{b. Tanda 1 (Seorang lelaki)}

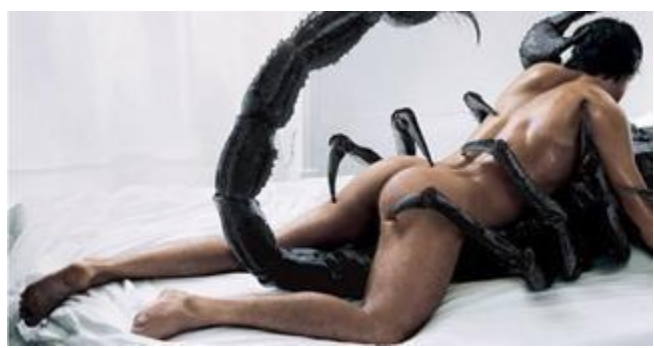

Dalam poster iklan ini, denotasi ditampilkan dengan seorang telanjang yang ditunjukan dengan gaya rambut pendek berwarna hitam dan postur tubuh yang proporsinya menunjukan kelelakian dengan kaki berbulu dan keringat dibadannya. Seperti diungkapkan Heidi (2007) "Men have more bodily hair than women do, especially on the chest and extremities". Dengan demikian dapat dikatakan bahwa orang yang terdapat dalam poster tersebut adalah lakilaki. Secara konotasi, hal ini menyiratkan pesan dalam poster ini lebih fokus dialamatkan atau ditujukan pada subjek lelaki muda. Dalam pasangan poster ini, juga ditampilkan versi lain poster dengan target utama perempuan.

\section{c. Tanda 2 (Jeans / Denim)}

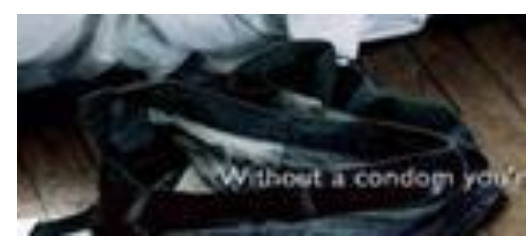

Denotasi yang berikutnya adalah celana jeans yang ditampilkan dalam poster, celana jeans memiliki konotasi gaya hidup bebas \& kasual, dimana celana jeans juga mencerminkan suatu kalangan masyarakat tertentu secara umum. Seperti diungkapkan oleh Daniel Miller dan Sophie Woodward (2007), "Furthermore the very anonymity and ubiquity of jeans protects from judgement. You may not be especially right, but you can't go far wrong with denim jeans." Dengan demikian penggunaan jeans (denim) merupakan hal yang melambangkan kebebasan serta sebagai pakaian yang sangat umum. "...denim is likely to become if anything more and more powerful as the central foundation of the individual's wardrobe, and commerce has to simply try and 
adapt to this use of denim." Daniel Miller dan Sophie Woodward (2007). Dengan demikian konotasi dalam tanda ini adalah selain ditujukan pada mereka yang memiliki gaya hidup bebas juga secara umum dapat terjadi pada siapa saja.

\section{d. Tanda 3 (Buku-buku)}

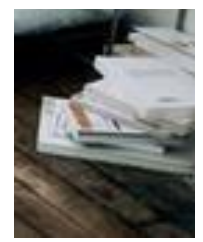

Denotasi yang ditampilkan melalui beberapa buku yang tertumpuk tidak rapih dibawah meja. Secara konotasi, buku-buku tersebut mengkonsepkan keterpelajaran. Menurut Angelita Williams (2009) “...books offer a chance to be entertained, educated and emerge a much more well-read individual". Sehingga buku ini berkonotasi pada pelajar.

\section{e. Tanda 4 (Ruang kamar)}

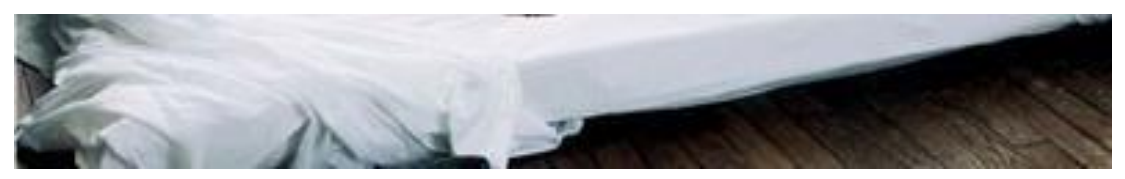

Ruang kamar dengan lantai kayu dan kasur tanpa ranjang yang dimunculkan dalam poster, memiliki makna konotasi ekonomi yang tidak atau belum mapan secara finansial, menunjukan seperti sebuah asrama, apartemen atau kamar kost yang erat dengan suatu kalangan di masyarakat.

\section{f. Tanda 5 (Kalajengking)}

Imaji yang ditampilkan adalah seekor kalajengking hitam yang besar. Paradigma yang muncul adalah keluarga antropoda berbisa yang membunuh secara perlahan, menurunkan kekebalan tubuh lawan untuk memangsa, sangat mungkin ditemukan dimana saja termasuk dipekarangan rumah di kawasan Perancis. "Scorpions are members of the class Arachnida and are 
closely related to spiders, mites, and ticks. ... 30 or 40 have strong enough poison to kill a person." National Geographic (2009). Secara konotasi, kalajengking hitam besar ini memberikan konsep eksotis, mengerikan dan memiliki racun berbahaya yang dapat mematikan dengan cara perlahan-lahan dan merupakan analogi dari penyandang virus HIV yang bisa ada disekitar kita.

\section{Relasi Antara Tanda}

Dari tanda-tanda diatas, maka terdapat relasi anta tanda yang dapat menjadi sebuah pemahaman terkait imaji-imaji yang dihadirkan dalam poster.

\section{a. Relasi 1 (Ruangan - kasur - celana jeans - buku-buku)}

Relasi yang terjadi dalam tanda-tanda ini menampilkan konsep keterpelajaran dengan gaya hidup bebas dan kebelum-mapanan ekonomi, hal ini merupakan transfer atau proses pemindahan satu sistem tanda ke sistem tanda yang lain dimana didalamnya terjadi analogi. Relasi ini menganalogikan kalangan mahasiswa/terpelajar dengan gaya hidup bebas seperti di apartemen, asrama atau kostan yang sering kali menjadi pelaku seks bebas. "In fact, sometimes people in the dorms might have sex in the same room as their roommates! It sounds crazy, but it does happen". Dikutip dari scholarshiphunter.com (2009). Ditambah lagi dengan kondisi Perancis yang memiliki masalah sex bebas dikalangan pelajarnya. Ini merupakan sebuah konsep utama dalam membidik target sasaran dari kampanye sosial ini.

"France is struggling with boundaries: the public portrayal of sex and sexuality, the limits of privacy for its public figures. This is the case, even though historically, the French are much less conflicted than Americans when it comes to sex. France is, after all, a country where the very proper National Library recently mounted a 16-year-andolder-only exhibition of its vast collection of erotica." Dikutip dari Elaine Sciolino (2008). 


\section{b. Relasi 2 (Lelaki - Kalajengking)}

Apabila ditelaah lebih jauh, hubungan antara manusia lelaki dan kalajengking merupakan hubungan antara tanda yang paling utama, dimana dari sisi tata letak, imaji tersebut ditampilkan kontras menjadi center of view diantara imaji-imaji yang lainnya.

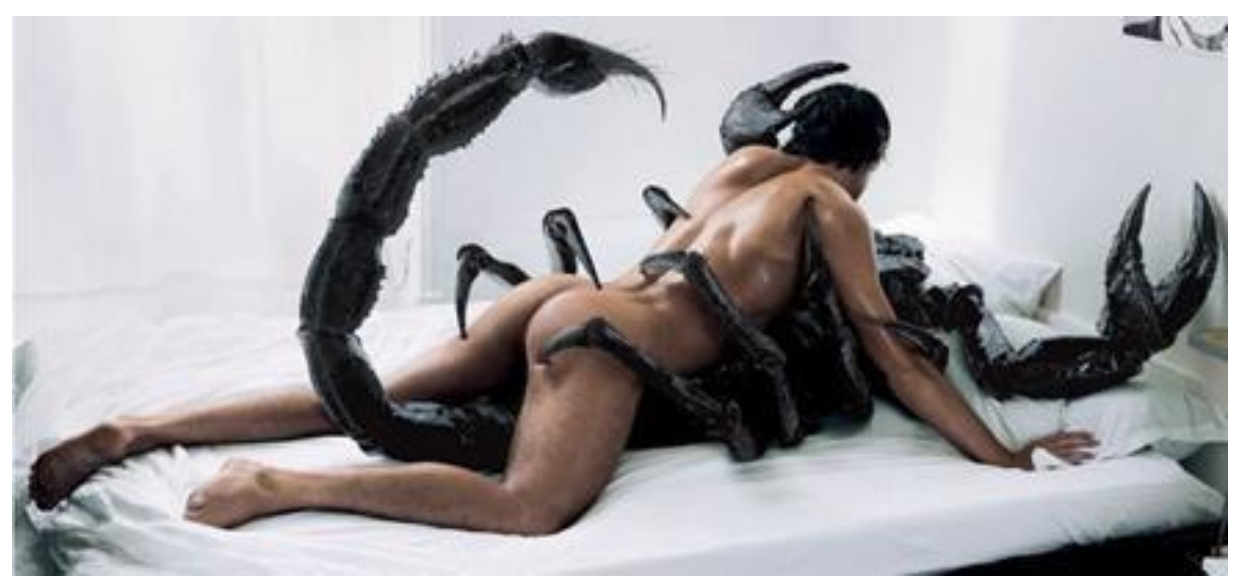

Kalajengking hitam ini merupakan paradigma yang digunakan untuk menampilkan atau menggantikan penyandang virus HIV. Tungkai ekor kalajengking beracun yang siap menyengat lawannya memberikan kesan menakutkan yang digunakan untuk menakuti atau mengingatkan audiens dalam melakukan hubungan seks aman. "A Scorpion often kills its prey with venom. But a Scorpion doesn't use fangs to deliver its poison. It uses the stinger at the end of its tail. First, the Scorpion grabs its prey with its claws. Then it raises its tail up and over its head to sting its prey." Animal Planet (2009). Dengan demikian, dalam poster ini penyandang HIV yang membawa virus mematikan dianalogikan seperti seekor kalajengking beracun yang dapat menyengat.

\section{KESIMPULAN}

Poster iklan kampanye layanan masyarakat mengenai penggunaan kondom untuk hubungan seks yang aman ini menggunakan metafora. Tata letak yang menjadikan 
imaji adegan hubungan seks antara lelaki dan kalajengking menjadi pesan utama yang ingin disampaikan pada audiens sehingga diletakan pada bagian tengah. Imaji-imaji yang lain digunakan untuk memperkuat pesan-pesan sehingga diletakan pada bagian yang kurang terekspos. Pesan ditujukan utamanya untuk para lelaki kalangan mahasiswa/terpelajar yang tinggal di asrama atau kostan yang sering menjadi pelaku seks bebas di Perancis. Hal ini ditunjukan dengan relasi antara tanda-tanda seperti celana jeans, buku-buku dan ruangan kamar yang mengkonotasikan gaya hidup pelajar/mahasiswa. Konsep utama yang ingin disampaikan adalah untuk berhati-hati dalam melakukan hubungan seks bebas, dimana pasangan yang bisa ditemukan sembarangan bisa saja menyandang virus HIV Aids yang bisa menular secara perlahan-lahan tanpa disadari. Pesan ini dimetaforakan dengan imaji kalajengking hitam dan besar. Pesan imaji diperkuat dengan pesan linguistik untuk menggunakan kondom agar terjaga dari virus HIV Aids.

\section{DAFTAR PUSTAKA}

Heidi. 2007. Difference between male and female structures (mental and physical). Dikutip dari http://www.steadyhealth.com/articles/Difference_ between_male_and_female_structures_mental_and_physical_a613.html. Diakses pada 20 April 2009.

Miller, Daniel., Woodward, Sophie. 2007. A Manifesto for the Study of Denim. Dikutip dari http://www.ucl.ac.uk/anthropology/people/academic _staff/d_miller/mil-12. Diakses pada 21 April 2009.

National Geographic. 2009. Scorpion. Dikutip dari http://animals. nationalgeographic .com/animals/bugs/Scorpion/. Diakses pada 01 Agustus 2009.

Planet Animal. 2009. Scorpion. Dikutip dari http://animals.howstuffworks.com /arachnids/Scorpion-info.htm. Diakses pada 21 April 2009. 
Piliang, Yasraf Amir. 2004. Hipersemiotika: Tafsir Cultural Studies atas Matinya Makna. Jalasutra: Yogyakarta.

Piliang, Yasraf Amir. 2008. Multiplisitas dan Diferensi: Redefinisi Desain, Teknologi dan Humanitas. Jalasutra: Yogyakarta.

Scholarshiphunter. 2009. SEX in the DORMS? Yes, it does happen. Dikutip dari http://www. scholarshiphunter.com /sexinthedorms.html. Diakses pada 21 April 2009.

Sciolino, Elaine. 2008. France. Sex. Problem? . Dikutip dari http://www.nytimes.com/2008 /10/30/fashion/30cliente.html? pagewanted=all\&_r=0. Diakses pada 01 Agustus 2009.

Williams, Angelita. 2009. The 100 Essential Books You Should Have Read in College. Dikutip dari http://www.onlinecollegecourses.com /2009/07/30/the100-essential-books-you-should-have-read-in-college/ . Diakses pada 01 Agustus 2009. 